\title{
Moisture Inhibits the Decomposition Process of Tissue Buried in Sea Sand: A Forensic Case Related Study
}

Franklin R.W. van de Goot ${ }^{1,2 *}$, Mark P.V. Begieneman ${ }^{1,2,4}$, Mike W.J. Groen ${ }^{1,3}$, Reza R.R. Gerretsen ${ }^{1,3}$, Maud A.J.J. van Erp ${ }^{2}$ and Hans W.M. Niessen ${ }^{2}$

${ }^{1}$ Centre for Forensic Pathology B.V. 3741 GK Baarn, the Netherlands

${ }^{2}$ ICaR-VU, Department of Pathology and Cardiac Surgery VU Medical Centre, De Boelelaan 1117, 1081 HV Amsterdam, the Netherlands

${ }^{3}$ Barge's Anthropologica, Department of Anatomy, Leiden University Medical Centre, Eindhovenweg 20, 2333 ZC Leiden, the Netherlands ${ }^{4}$ Netherlands Forensic Institute (NFI) Laan van Ypenburg 6, 2490 GB the Hague, the Netherlands

\begin{abstract}
Many aspects influence the decomposition process of a body and, as such, are important in forensic science for estimation of the post mortem interval. In a recent forensic case, a missing man was found buried in sea sand. The post mortem interval estimation as obtained at autopsy was quite different to the actual period this man was missing In the present study, we have set up an artificial decomposition model to study the effect of sea soil and moisture, relevant to this particular case, on the decomposition mode.

Pig (Sus domesticus) legs were buried in 50 litres of sea sand and control sand (woodland sand) respectively, within containers for 1,2 and 3 months. The sand was evaluated using routine pedological analysis. The legs were analysed using AZAN staining and microscopically scored for their decomposition grade. In the second part of the study, the effect of moisture hereon was analysed.

Pedological analysis did not show significant differences in composition between the sea- and woodland sand Although an increase in decomposition grade was found in both soils over time, no differences in decomposition grade were found. In the second part of the study, however, we found a significant decrease in decomposition score in legs buried in wet, soaked sea sand compared to those buried in dry sea sand. Soaked means a small layer of water was seen on the container's surface.
\end{abstract}

We have successfully developed an in vitro decomposition model in order to address taphonomic questions related to a forensic case and have found that moisture inhibited the process of decomposition in sea sand.

Keywords: Taphonomy; Decomposition; Moisture; Histology; PMI

\section{Introduction}

Taphonomy is the science of the laws of embedding [1] combining geological, biological and historical approaches into one methodology [2-15]. Forensic taphonomy integrated the concept of taphonomy within the field of forensic science. This is applied in the study of human decomposition, the determination of the Post-Mortem Interval (=PMI) or Post-Burial Interval (= PBI), the analysis of the cause and manner of death, and the distinction between products of human behaviour from those created by natural factors such as, for instance, animal activity and the identification of human remains sites [16-18].

Decomposition on a macroscopic level is well documented from ancient literature (the Gilgamesh Epic quotes maggots in a human body infestation in a warm environment [19]) to modern literature. In particular, the formation of livor mortis, rigor mortis and temperature are well-documented [20-23]. Nevertheless, these aspects are signs of early decomposition. The ongoing stages, in particular, are less described.

It is known that the longer the post mortem time lapse is, the more difficult it is for adequate histopathological conclusions sites [24]. Most of the articles dealing with post mortem histopathology pinpoint organ pathology and the level of certainty one still has in using histological techniques. Time related degeneration of normal histological structures such as muscle or nerves that has been systematically documented is very hard to find in literature at present.

The dermis consisting of epidermis with several layers of cells, divided by a basal membrane from the dermis, is a collagen rich structure containing vessels, hairs and glands, subcutaneous fatty tissue and the deeper muscular tissue, along with the superficial and deeper localised arteries and nerves [25]. It is likely that the decomposition of the epidermis is influenced more by the surrounding soil than, for instance, the deep muscles. On the other hand, the case of a complete body bacterial flora from the inside can give rise to other mechanisms of decomposition.

In this study, we investigated the degeneration of several clearly recognisable histological structures over time on a quantitative scale.

Recently we encountered the importance of the above mentioned taphonomic variables in a forensic case of a missing man that was buried in sea sand (for more details, see the Materials and Methods section) in the early spring of 2008 in the western part of the Netherlands. In this particular case, the initial Post Mortal Interval (=PMI) estimation did not coincide with the period the man was missing. This raised the

*Corresponding author: F.R.W. van de Goot, Centre for Forensic Pathology B.V. 3741 GK Baarn, the Netherlands, Tel: +31 35 5430332; Fax: +31 35 5430019; E-mail: forensischpatholoog@live.nl

Received January 20, 2013; Accepted January 30, 2013; Published February 01,2013

Citation: van de Goot FRW, Begieneman MPV, Groen MWJ, Gerretsen RRR, van Erp MAJJ, et al. (2012) Moisture Inhibits the Decomposition Process of Tissue Buried in Sea Sand: A Forensic Case Related Study. J Forensic Res 3:176. doi:10.4172/2157-7145.1000176

Copyright: (C) 2012 van de Goot FRW, et al. This is an open-access article distributed under the terms of the Creative Commons Attribution License, which permits unrestricted use, distribution, and reproduction in any medium, provided the original author and source are credited. 
question of whether this PMI estimation was, therefore, incorrect. To the best of our knowledge however, research related to the effect of sea sand and/or moisture on the decomposition state of a human body as such is lacking. Therefore, we performed a taphonomy study in an in vitro decomposition model to analyse whether sea sand preserves organic material better than woodland soil and whether moisture has a significant impact on this process.

\section{Materials and Methods}

\section{Case report}

Remains of an unknown adult male were found in the western part of the Netherlands in the early spring of 2008 during construction work for an infrastructural project. These remains were accidentally removed from the burial pit by a large excavator and transported over a distance of circa 700 metres to a secondary location. The original burial pit with an average depth of approximately $140 \mathrm{~cm}$ had been dug in sand of medium texture $(0.5-0.25 \mathrm{~mm})$ and marine origin. In the Netherlands, sea sand is often used to improve the ground texture needed for the foundation of roads or other structures. The discovered body was clothed in a normal fashion according to the weather at the time (i.e. 2 thin layers of clothing). The body was severely damaged by the movement of the draglines. Although there were clear signs of decomposition, the hair of the victim was firmly attached to the head, the epidermis was still present and almost no green coloration was seen. Almost no gaseous formation was noticed and fluid blood was still available. Due to the physical state of the remains, the time between death and discovery, the so-called Post Mortem Interval (= PMI), was estimated at approximately one to two weeks (Figures 1a and 1b). Green discoloration of the body was limited directly after excavation. The green discoloration as noticeable on figure 1a, however, rapidly progressed in this way during the time subsequent to excavation. The soft tissues (Figure 1b) had a more or less normal aspect at autopsy. Overall, this was inconsistent with the fact that after his positive identification this man appeared to be missing for approximately three months. If the initial PMI estimation was correct, an explanation for the approximately two-and-half month episode for which he was reported missing had to be found. If the initial estimated PMI was incorrect, however, there should be an explanation for which factors contributed to this exceptionally good preservation of the remains. In order to test this last hypothesis, the present study was performed to analyse whether sea sand preserves organic material better than woodland sand. In addition, the impact of the level of moisture was examined since the late autumn and winter periods (i.e. the period during which the man was missing) in the Netherlands are notorious for their prolonged periods of heavy rainfall.

\section{Experimental design}

Since there are ethical restrictions within the Netherlands for the use of human tissues in taphonomic research, the experiment was performed on pig tissue (Sus domesticus). In previous taphonomic studies, it has been shown that pig tissue decomposes more or less identically to human tissue, although this has not been studied in sea sand before [26-37].

In total, 180 pig legs were used for this experiment, a total organic mass of approximately $50 \mathrm{~kg}$. All legs were obtained from an abattoir while still fresh and were cleaned with hot water according to standard slaughter protocols. As a result, no pigs were harmed for the purpose of the study. These legs did not differ significantly with respect to weight and mass (not shown because all samples were taken from the same place of the legs, approximately $1 \mathrm{~cm}$ below the skin at the backside of the leg. We assumed that slight differences in weight and size will not give significant alterations).

The experiments took place at the same time of the year - one year after the victim was reported missing. The location of the burial site of the victim was $75 \mathrm{~km}$ from the research facility and provided a more or less similar temperature, humidity degree and sea level according to the Dutch meteorological centre who compared tables of precipitation and temperature where established. Although both periods were not identical, the authors accepted the differences as more or less comparable. During a relatively cold 14 day period in January 2009, the containers were loosely covered with industrial plastic and stored in a more protected area. The distance of only $75 \mathrm{~km}$ away from the North Sea was accepted climatologically as being similar.

Plastic containers $(40 \times 35 \times 35 \mathrm{~cm})$ were used to store the legs in both experiments. Pig legs with skin attached were buried in two different sands: one consisted of sea sand, identical to the sand in which the remains of the adult man were found (Figure 1C) and the other control sand was woodland sand, sampled in a nearby area (Figure 1d). The choice for woodland sand as control sand was because much of the knowledge regarding the speed of decomposition of buried human bodies within the Netherlands is derived from information from illegal burials in woodland areas. Woodland soil is common yellow soil found in many places in the deeper earth layers in the Netherlands usually after approximately 1 metre of organic soil yellow sand is found, composing of particles transported by the rivers from central Europe and by the last ice age from the north of Europe. Both sands were sampled from the a) (i.e. surface soil), b) (i.e. subsoil) and c) (i.e. parent material) horizons of the soil profile. $2 \mathrm{~m}^{3}$ of each soil type was used.

Subsequently, two separate experiments were performed. The first experiment (80 legs) was set up to examine the difference in speed of tissue degradation between the wet sea soil and wet woodland soil, therefore independent of the degree of moisture and at identical

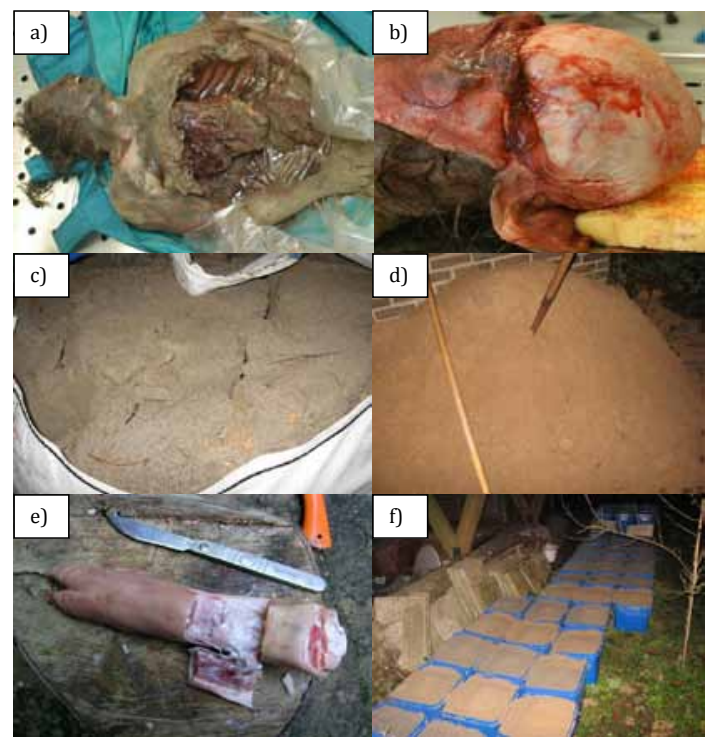

Figure 1: Macroscopic pictures of the victim and the in vitro experiments.

a) the body of the victim, b) the head of the victim with preserved soft tissue, c) sea sand, d) woodland sand e) sampling of fresh material f) containers outside in open air. 
(surrounding) temperatures. The second experiment (90 pig legs) was performed to examine the putative difference in degradation speed of the pig legs between dry and wet sea soil but, once again, both were at identical temperatures. The 10 remaining legs were used as negative controls (Table 1).

During the first experiment, all containers were placed in open air, generating wet sea sand and woodland sand, although the bottom of the container was perforated in order to drain rainwater. First of all, all containers were filled with $10 \mathrm{~cm}$ of woodland sand or sea sand and then a pig leg was placed on, positioned in such a way that they did not touch the plastic walls of the container. The containers were then covered with $25 \mathrm{~cm}$ of soil that was firmly pressed. Ten containers contained pig legs without sand; ten legs were sampled immediately (Figure 1e). Finally, all containers were placed outside, in the open air (Figure 1f) to simulate the conditions of the crime scene. After 1, 2 and 3 months ten legs of both sand types and controls (3 legs after 1 month, 3 legs after 2 months and 4 legs after 3 months) were excavated and sampled (Table 1).

During the second experiment, all $90(2 \times 45)$ containers were filled with sea sand up to $10 \mathrm{~cm}$. The legs were then placed on top of the soil once again positioned in such a way that they did not touch the plastic walls of the container. The containers were then covered with $25 \mathrm{~cm}$ of sand that was firmly pressed. In this experiment however, half of the containers were placed in open air, generating wet sea sand, whereas the other half of the containers were loosely covered with plastic, generating sea sand with less moisture than the uncovered containers. Samples were taken after a period of 1,2 and 3 months; 15 samples each time (Table 1). Due to an irrigation canal in the bottom of the containers, most of the rain water could easily pour away. Nevertheless, a small layer of water was observed during rainfall, making the sand Saturated. Saturated means a thin layer of water was permanently seen on top of the soil.

\section{Sampling method}

All samples were taken from the topside of the leg and contained both skin and muscle (Figure 1e). After sampling, all samples were fixed in $4 \%$ formalin and histologically processed (i.e. dehydrated and embedded in paraffin). After this, six-micrometre thick slides were processed for each sample and stained. For this routine, AZAN staining was performed to visualise connective tissue that was used for the microscopic scoring analysis (see below).

\section{Microscopic scoring analysis: decomposition score}

All slides were analysed and scored microscopically. For this, five different tissue structures were investigated separately, namely: dermis, fat tissue, muscle, blood vessels and nerves. To quantify the state of decomposition a scoring system of 0 to 3 was used. A typical example of the microscopic scoring analysis of the muscle, stage $0-3$, has been depicted in figure 2. As such, the score 0 was related to fresh tissue samples (no decomposition), the score 3 was related to an unburied sample after 1, 2 and 3 months (maximal decomposition) dependent on when exactly each particular sample was excavated. It has to be noted that the maximum score of 3 had already been achieved within the unburied control samples after just one month. All scores are explained in more detail in table 2.

\section{Statistical analysis}

The data derived from both experiments were analysed using

a) Type of samples used in the first experiment

\begin{tabular}{|l|c|c|c|c|c|c|}
\hline Buried / unburied & Control & Buried & Buried & Buried & Unburied & Unburied \\
\hline Time (months) & 0 & 1 & 2 & 3 & 1 \\
\hline $\mathbf{N}=$ & 10 & 20 & 20 & 20 & 3 \\
\hline
\end{tabular}

b) Type of samples used in the second experiment

\begin{tabular}{|l|c|c|c|c|c|}
\hline Sand type & Dry & Wet & Dry & Wet & Dry \\
\hline Time (months) & 1 & 1 & 2 & 3 & 3 \\
\hline $\mathbf{N}=$ & 15 & 15 & 15 & 15 & 15 \\
\hline
\end{tabular}

Table 1: Explanation of the samples of the experiment.

\begin{tabular}{|c|c|c|c|c|}
\hline & Score 0 (fresh samples) & Score 1 & Score 2 & Score 3 (unburied samples) \\
\hline Dermis & $\begin{array}{l}\text { Dermis appeared in finely } \\
\text { orientated fibres, the edges were } \\
\text { very sharp and there were no lyses } \\
\text { of collagen or adnexal structures. }\end{array}$ & $\begin{array}{l}\text { Dermis appeared in finely orientated fibres, } \\
\text { and lyses of collagen and adnexal structures } \\
\text { occurred occasionally. }\end{array}$ & $\begin{array}{l}\text { Dermis showed clear lyses of } \\
\text { collagen and adnexal structures } \\
\text { but was still recognisable as } \\
\text { dermis. }\end{array}$ & $\begin{array}{l}\text { Dermis was only appearing in } \\
\text { massive coagulating lyses of } \\
\text { collagen and adnexal structures. }\end{array}$ \\
\hline $\begin{array}{l}\text { Fatty } \\
\text { Tissue }\end{array}$ & $\begin{array}{l}\text { Fat tissue was sharply lined with } \\
\text { smooth edges and clear nuclei. }\end{array}$ & $\begin{array}{l}\text { Fat tissue was occasionally not sharply lined } \\
\text { or the chromatin pattern of the nucleus was } \\
\text { obviously degenerated but without damage } \\
\text { to the outer structure of the nucleus. }\end{array}$ & $\begin{array}{l}\text { Fat tissue was clearly showing } \\
\text { signs of lyses, but the actual } \\
\text { structure of the fatty tissue was } \\
\text { easily recognisable. }\end{array}$ & $\begin{array}{l}\text { Fat tissue was almost completely } \\
\text { degenerated, appearing only as } \\
\text { ghostly contours. }\end{array}$ \\
\hline Muscle & $\begin{array}{l}\text { Muscle was sharply edged; there } \\
\text { was no sign of fragmentation and } \\
\text { no degeneration of the interstitial } \\
\text { fibres. }\end{array}$ & $\begin{array}{l}\text { Muscle was occasionally less sharply } \\
\text { edged and there were minor signs of } \\
\text { fragmentation. }\end{array}$ & $\begin{array}{l}\text { Muscle showed clear } \\
\text { fragmentation but not all fibres } \\
\text { were damaged and/or the } \\
\text { structure of the muscle was still } \\
\text { recognisable. }\end{array}$ & $\begin{array}{l}\text { Muscle showed massive lyses and } \\
\text { as such the muscle structure was } \\
\text { now only recognisable by its colour, } \\
\text { not by its histological appearance. }\end{array}$ \\
\hline $\begin{array}{l}\text { Blood } \\
\text { vessels }\end{array}$ & $\begin{array}{l}\text { Blood vessels were clearly } \\
\text { consisting of several layers of } \\
\text { muscle and collagen and the } \\
\text { endothelium was undamaged. }\end{array}$ & $\begin{array}{l}\text { Blood vessels were clearly consisting of } \\
\text { several layers of muscle and collagen, } \\
\text { however with minor signs of lyses and } \\
\text { damage. }\end{array}$ & $\begin{array}{l}\text { Blood vessel showed clear lyses, } \\
\text { but the actual structure was still } \\
\text { recognisable. }\end{array}$ & $\begin{array}{l}\text { Blood vessels appear only as } \\
\text { contours. No histological structures } \\
\text { were recognisable. }\end{array}$ \\
\hline Nerves & $\begin{array}{l}\text { Nerves were sharply edged, there } \\
\text { were no signs of lyses and the } \\
\text { axon structure was undamaged. }\end{array}$ & $\begin{array}{l}\text { Nerves were occasionally less sharply } \\
\text { edged, there were minor signs of lyses } \\
\text { and the axon structure showed minor } \\
\text { deterioration. }\end{array}$ & $\begin{array}{l}\text { Nerves were still easily } \\
\text { recognisable but the internal } \\
\text { structure showed clear signs of } \\
\text { lyses. }\end{array}$ & $\begin{array}{l}\text { Nerves appeared in ghostly contours } \\
\text { and no separate capsule or axon } \\
\text { structure was identified. }\end{array}$ \\
\hline
\end{tabular}

Table 2: Histological aspects of the scoring system. 
Citation: van de Goot FRW, Begieneman MPV, Groen MWJ, Gerretsen RRR, van Erp MAJJ, et al. (2012) Moisture Inhibits the Decomposition Process of Tissue Buried in Sea Sand: A Forensic Case Related Study. J Forensic Res 3:176. doi:10.4172/2157-7145.1000176

Page 4 of 8

conventional univariate analysis with proprietary statistical package SPSS, using the Wilcox ranking test.

\section{Meteorological data}

To extrapolate the original burial findings of the victim to the decomposition in vitro model, meteorological data concerning the temperature and rainfall were obtained from the Royal Netherlands Meteorological Institute (KNMI) in De Bilt. Precipitation amounts in time are represented in figure 3.

It was noticed that a significant amount of rainfall did occur during the period in which the man went missing, namely $370 \mathrm{~mm}$ in total (KNMI). It is worth noting that this amount was higher than the average amount for this time of year, $280 \mathrm{~mm}$ (KNMI). For this reason, the effect of moisture on the decomposition process of the pig legs in sea soil was then studied. Temperature was not calculated in this model for the temperatures at a depth of $140 \mathrm{~cm}$ at this spot in the Netherlands are often low and fluctuate with ground water rising, not directly with surface temperature alterations.

\section{Archaeological and pedological analysis}

Following the discovery of the remains, an archaeological survey was performed at the site. During this survey, the remnants of the burial pit were found. This pit was originally approximately $1.4 \mathrm{~m}$ deep, but only $15 \mathrm{~cm}$ (i.e. the bottom of the pit) could be examined in situ because the pit was almost completely destroyed by a large excavator. The average soil temperature measured at $1.4 \mathrm{~m}$ below the surface level was $7.8^{\circ} \mathrm{C}$ at the moment of excavation. The average temperature measured at the surface level was $9.2^{\circ} \mathrm{C}$. The bottom of the pit was situated circa $15 \mathrm{~cm}$ above the groundwater level. It was not possible to measure the $\mathrm{pH}$ value and moisture of the pit soil reliably due to the heavy soil disturbance at the site.

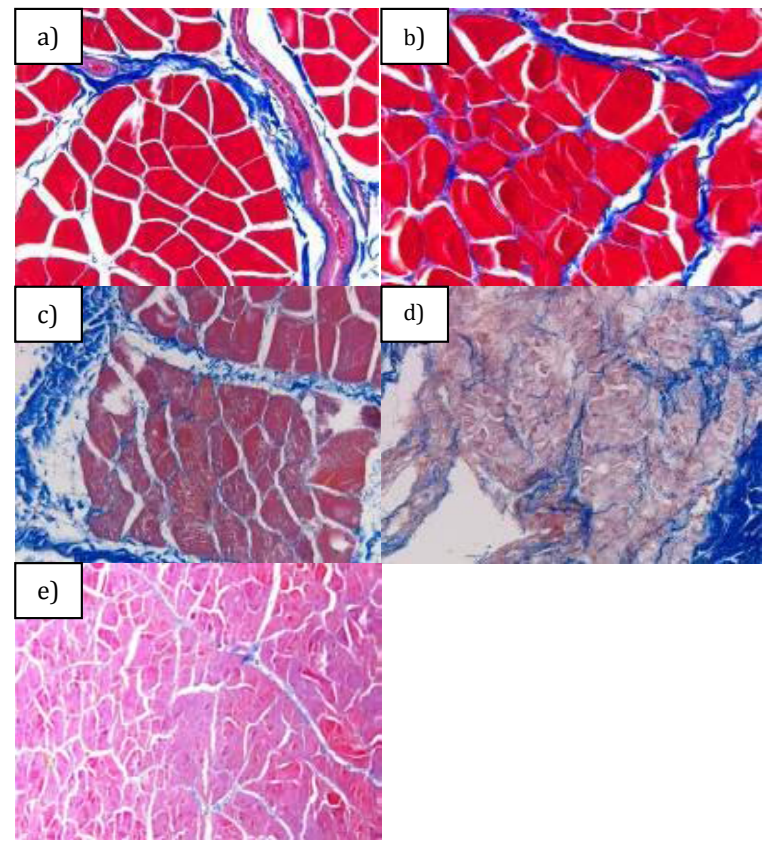

Figure 2: Microscopic pictures of the muscle, stained with AZAN.

a) Score 0 pig leg, b) Score 1 pig leg, c) Score 2 pig leg, d) Score 3 pig leg, e) Sample victim, Magnification 400 X. Muscle (neck region) of the victim with decomposition score 3,e) Magnification $400 \mathrm{X}$.

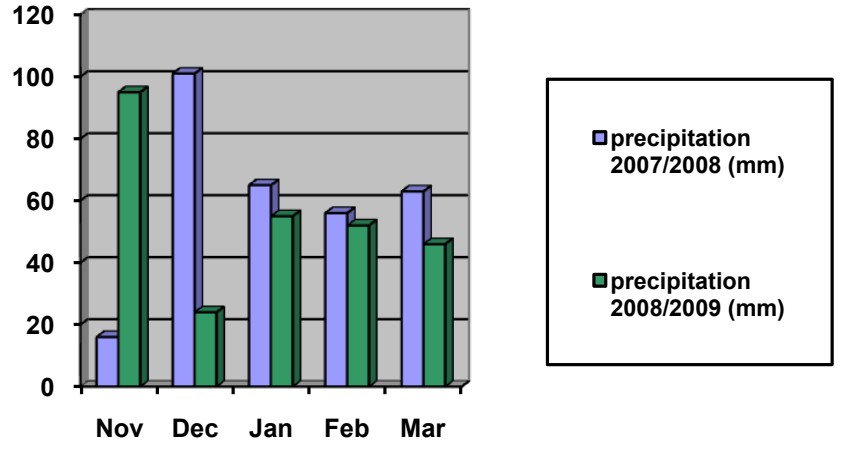

Figure 3: Precipitation analysis in $2007 / 2008$ and $2008 / 2009$ in several months in the Netherlands. $2007 / 2008$ is shown in blue, $2008 / 2009$ is shown in green.

A pedological analysis was performed in sand samples derived from the first experiment, including two sea sand samples and two woodland sand samples that were collected at the start and at the end of the entire experiment. Pedological analysis consisted of a Thermo Gravimetric Analysis (TGA), an X-ray fluorescence spectrometry analysis (XRF) and a particle size analysis 8 (Table 3 and figure 4).

\section{Thermo-gravimetric analysis (TGA)}

The organic substance and carbonate content of the samples were determined by Thermo-gravimetric analysis. During this analysis, the loss of weight was measured in an equation with time and temperature. Data retraction took place in the range from 25 to $1000^{\circ} \mathrm{C}$. All analyses were performed in duplicate. The analyses were performed on a TGA601 machine from LECO Corporation up to $1000^{\circ} \mathrm{C}$ with a speed of $10^{\circ} \mathrm{C}$ per minute medium flow speed. We used ceramic cups and samples of $2.5 \pm 0.4 \mathrm{~g}$.

\section{Rontgen-fluorescence spectrometry (XRF)}

$4.5 \pm 0.005 \mathrm{~g}$ samples were used in aluminium cups. $10 \%$ weight equivalent of EMU (glue substance) was added and incorporated in an Agate mill and pulverised in approximately 15 minutes. The resulting substance was added to aluminium cups and placed in a corrosionfree steel cylinder. Plastic foil was added to prevent contamination of the steel. The cylinder was placed in a press for 30 seconds with a compression force up to $2000 \mathrm{~kg}$. Pressure release to $0 \mathrm{~kg}$ in approximately 30 seconds. Material was stored in an exsiccator until analysis. Analysis was performed with a MagiX PRO XRF system from Spectris CO. LTD. The software used was SuperQ manager.

\section{Grain size analysis}

$500 \mathrm{mg}$ of sand together with $200 \mathrm{mg}$ of clay was put with $5 \mathrm{ml}$ of $30 \% \mathrm{H}_{2}$ and boiled to remove organic material. During this heating process, extra-demineralised water was added. After cooling until approximately $40^{\circ} \mathrm{C} 5 \mathrm{ml} 10 \% \mathrm{HCl}$ was added before the samples where heated again for approximately 1 minute. After this, $750 \mathrm{ml}$ of demineralised water was added. After sedimentation (overnight) the samples where decanted and $300 \mathrm{mg}$ of $\mathrm{Na}_{4} \mathrm{P}_{2} \mathrm{O}_{7} \cdot 10 \mathrm{H}_{2} \mathrm{O}$ (sodium pyrophosphate) was added before heating. After cooling, the samples were analysed with a laser particle a22, C-version, VUmc, and Laboratory for Sediment Analysis. 
a) Results of TG analysis

\begin{tabular}{|l|c|c|c|}
\hline Sample & Water & Organic material & Glow (NEN5754) \\
\hline & $\%$ & $\%$ & Carbonate \\
\hline 1: Woodland at start, WS & 0.106 & 0.115 & 0.337 \\
\hline 2: Sea at start, SS & 0.136 & 0.167 & 0.528 \\
\hline 3: Woodland at end, WE & 0.055 & 0.101 & 0.393 \\
\hline 4: Sea at end, SE & 0.088 & 0.091 & 0.726 \\
\hline
\end{tabular}

b) Results of XRF analysis

\begin{tabular}{|c|c|c|c|c|c|c|c|c|c|c|c|c|c|c|}
\hline Spl & Conc & $\mathrm{Fe} 2 \mathrm{O} 3$ & $\mathrm{MnO}$ & TiO2 & $\mathrm{CaO}$ & K2O & P2O5 & SIO2 & AL2O3 & MGO & NA2O & $\mathrm{Zn}$ & $\mathrm{Cu}$ & $\mathrm{Ni}$ \\
\hline WS & 87,22 & 0,60 & 0,01 & 0,10 & 0,27 & 1,28 & 0,04 & 81,08 & 3,01 & 0,24 & 0,59 & 22,85 & 2,59 & 9,43 \\
\hline SS & 88,48 & 0,62 & 0,01 & 0,12 & 3,69 & 1,24 & 0,04 & 79,03 & 2,75 & 0,38 & 0,59 & 15,03 & 1,59 & 8,29 \\
\hline WE & 87,59 & 0,55 & 0,01 & 0,09 & 0,31 & 1,26 & 0,03 & 81,65 & 2,90 & 0,21 & 0,58 & 17,46 & 1,87 & 9,91 \\
\hline SE & 87,73 & 0,81 & 0,02 & 0,13 & 5,02 & 1,36 & 0,05 & 75,78 & 3,39 & 0,53 & 0,63 & 18,60 & 2,23 & 10,40 \\
\hline
\end{tabular}

Tables 3: Archeological and pedological analysis.

\section{Results}

\section{Pathological analysis of the first experiment: wet sea soil versus wet woodland soil}

The first study was whether significant differences were present between sea soil and woodland soil. For this pedological analysis (grain size, chemical and physical composition) was performed. Determination of the amount of organic matter in both soils showed that this was less than $0.2 \%$. The water content of both soils at the start and the end of the experiment were also comparable, namely less than $0.14 \%$. As expected, the only differences between sea soil and woodland soil were found in the content of calcium carbonate and in calcium oxide levels; both were 10 times higher in sea soil compared with woodland soil. Although it is known that both chemical compounds have hygroscopic potential and could therefore theoretically influence the moisture, we did not find this in our analysis (see above).

In addition, only small, but not significant, differences were found in the size of soil particles in the different soils. Namely, the sea sand showed minor reduction in grain size and a higher size variety compared to fresh woodland soil (average respectively $1.64 \mu$, SD 1.28 versus $1.79 \mu$ SD 1.40).

The macroscopic aspects of the pig legs in the in vitro decomposition model were then analysed. No significant differences were found between legs stored in sea sand and legs stored in woodland sand at all three time points (not shown). Nevertheless, there were alterations in time between the freshly isolated material and the tissue excavated after one and three months. Namely, an increase in tissue solubility was found with increasing excavation time. This difference, however, could not be quantified for further statistical analysis.

Subsequently, putative microscopic differences were studied. As expected, the microscopic differences between fresh and unburied material were drastic. In that, all structures were optimally observed in the fresh material, whereas almost complete lyses were found in the unburied material. Microscopically, a significant increase in decomposition score was found over time $(\mathrm{p}<0.05)$ for all five layers studied (respectively dermis, muscle, fat tissue, blood vessels, nerves) between the legs buried for one and two months, as well as between the legs buried for two and three months, as depicted in figure 5. This was observed both in legs buried in woodland sand and in legs buried in sea sand. However, no significant differences in decomposition scores were detected between tissues stored in wet woodland sand and tissues stored in wet sea sand under identical temperature and identical moisture.

\section{Pathological analysis of the second experiment: dry sea soil versus wet sea soil}

According to the first experiment, legs buried in wet sea sand showed a significant increase in decomposition scores between one as opposed two months and between two as opposed to three months (Figure 5) $(\mathrm{p}<0.05)$. It must be noted that there were differences in decomposition grade between the pig legs stored in the sea soil from experiment 1 and experiment 2 . The majority of these differences in decompositions score were, however, limited to 0.5 or less and therefore not significant. The time dependent increase in decomposition score was also found in legs buried in dry sea sand. Remarkably, however, the decomposition score was significantly higher in all five layers of legs buried in dry sea sand compared to legs buried in wet sea sand. This was found in legs buried for one, two and three months (Figure 6). This therefore indicates that moisture could play a crucial role in the period of decomposition in that humidity inhibits decomposition over time in sea sand.

Although the authors recognise that a direct comparison of the results from the in vitro decomposition pig leg model with the complexity of a complete decomposing body of the victim can be questioned, remarkable similarities in the decomposition mode of the buried victim (Figure 2) and that of the pig legs among the different tissues were noticed. Muscle tissue of the victim mostly appeared as AZAN recognisable contours (score 2) with great similarity to wet buried pig legs after 3 months old (Figure 2e). The dermal structures showed clear lyses and collagen degeneration, while the blood vessels and nerves were well preserved with degenerated but recognisable structures and were therefore also in line with wet pig legs buried for three months (not shown). The same was true for the fatty tissue that appeared in a clear state of lyses, which was still easily recognisable (not shown). As far as this is concerned, all five analyzed tissues of the victim showed decomposition scores that were comparable with the decomposition score obtained in pig legs buried for three months in wet sea sand.

\section{Discussion}

After death, human remains are subjected to the process of autolysis (i.e. enzymatic degradation of cells), putrefaction (i.e. degradation of soft tissues by anaerobic bacteria and fungi) and decay (degradation of soft tissues, mainly by aerobic decomposition and insects). Geoclimatic conditions, type of landscape, nature of parent soil material and the quality of the organic matter seem to dominate the speed of degradation [38]. It is generally accepted that burying does result in a 
decreased rate of degradation. This decrease seems to be regulated by a reduced presence of insects, the nature of the parent soil material, a decrease in soil temperature, high soil moisture, greater burial depth and the degree of physical protection (e.g. clothing or plastic covers) $[4,15,16,26,39-49]$.

In the present study, a case report was described of a man found to be buried in the western part of the Netherlands of which the post mortal interval was estimated at approximately one to two weeks, when in fact the man was missing for three months. Subsequently, the effect of the nature of the soil and moisture in a pig leg decomposition model was studied, as described in more detail in materials and methods. In addition, in legs buried in both sea sand (sand in which the man was buried) and in woodland sand (control sand), an increase in decomposition score over time was found, underlining the validity of the model to study the process of decomposition as such (Figures 5 and 6).

Using pedological analysis, differences between sea sand and woodland sand in chemical composition were detected, namely a level of calcium carbonate and oxide levels increased tenfold and reduced grain size in sea soil compared with woodland soil. Notwithstanding these differences, no effect on the decomposition grade was found in our decomposition model between wet sea sand and wet woodland sand (Figure 5). Although it is known that soil texture (i.e. grain size) and sand structure (i.e. compaction) can have a direct effect on the microbiological, chemical and physical reactions in the sand. Therefore on the sand's hydrological and diffusion properties $[36,38,46,49,50]$, it has been shown that the sand type [51] and soil microbe content [5052] are most likely to have a minor role during the early stages of the decomposition process.

Only a minor role for microorganisms in this type of soil is suggested due to the processing of the soil before using. Sea soil namely is brought up from the sea bed and left unprotected for a long time so that rain is able to wash out the majority of components. Further, the processing of the soil repeatedly disturbed the formation of solid structure. On the other hand, the woodland soil was brought up from a significant depth of several meters below the upper, biological active layer. Nevertheless, without any doubt it can be assumed that although the soil microbiological component is suggested to be of minimal influence in this case, the pre-existing microbiological presence (skin, intestines) are assumed to be of significant influence on decomposition speed. This influence is likely to occur due lower diffusion rate of decomposition gasses in water than they do in soil.

Apparently, the differences in grain composition and grain size we encountered in the present study are, in this case, not that important in the decomposition process we have studied.

It was found, however, that moisture did result in a significant

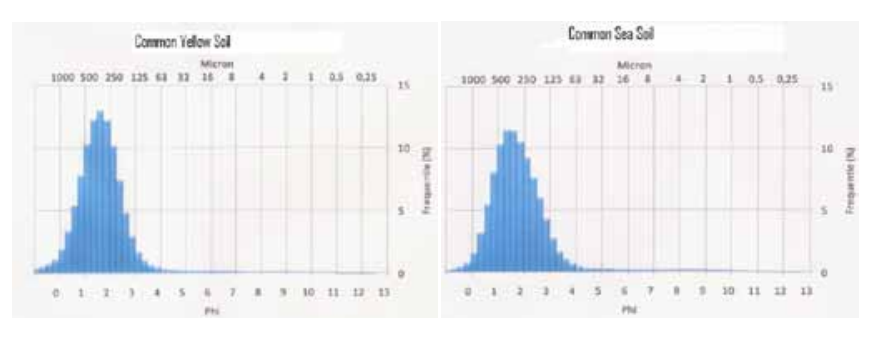

Figure 4: Grain size analysis, a): Common yellow soil, b) common sea soil. a)

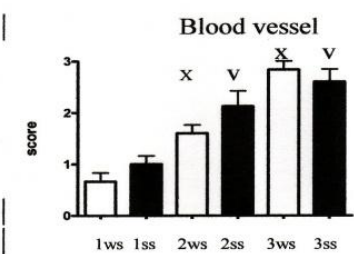

c)

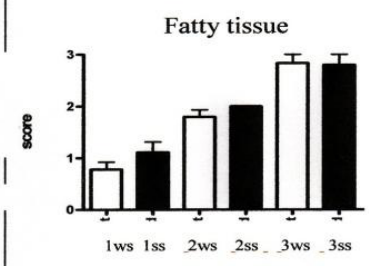

e)

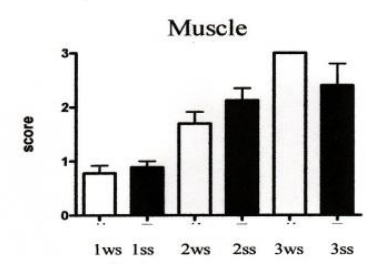

Figure 5: Decomposition score of the pig legs: wet sea soil (ss) compared with wet woodland soil (ws)

a) blood vessels, b) nerves, c) fat tissue, d) dermis, e) muscle.

Open bars: woodland soil; Closed bars: sea soil.

$x: p<0.05: 2$ months compared with 1 month;

$v$ : $p<0.05$ : 3 months compared with 2 months.

decrease in the decomposition score in legs buried in wet sea sand compared to legs buried in dry sea sand (Figure 5). In the literature, it was noticed that water has a preserving effect on decomposing bodies (Casper's law) [53]. The reason water preserve is likely due to the creation of a partially anaerobic environment [16].

When extrapolating the findings of the pig leg model to the particular case, it appeared that the winter of 2007 and early spring of 2008 , the probable period in which the man was buried, encountered a lot of rainfall. Since the soil in the burial pit was less compact than the surrounding soil, the porosity and permeability of the soil within the pit was greater than in the undisturbed area. Theoretically, the rainwater must have therefore descended from the upper surface down into the burial pit. Furthermore, the lack of vegetation approximately the pit must have promoted the flow of rainwater into the pit. Since the remains of the victim man appear to bury only $30 \mathrm{~cm}$ above the water table, it is also likely that this fluctuating table were exposed to the remains. The level of the water table and the descending rainfall must have led to increasingly waterlogged soil surrounding the human remains. According to our pig leg model, it is therefore reasonable to state that the rate of degradation of these remains was slowed down.

Soil temperature can also be a denominating factor [16,45$47,49,54,55]$. It is, for example, generally accepted that the degradation 
of organisms and their enzymes is greatly inhibited at temperatures below $10^{\circ} \mathrm{C}$ [37-52,54,56-59]. During the winter and early spring months, it is known that the soil temperature in the area in which the victim was found is lower than the $8^{\circ} \mathrm{C}$ measured during early spring. Since the degradation of biological tissues is slowed down beneath $10^{\circ} \mathrm{C}$, the low temperature in the burial pit could theoretically have played a crucial additional role in inhibiting the process of degradation of the remains in this particular case.

Another limitation of this study is that the victim was buried fully clothed while the pig samples were not. It is possible that clothing can play a role in the decomposition process. Many different types of clothing and fabrics are expected to have a deceleration influence on decomposition since they can shield oxygen and absorb moisture even in a dry period. In our model, we do not think that this effect is a major influence. a)

Blood vessel

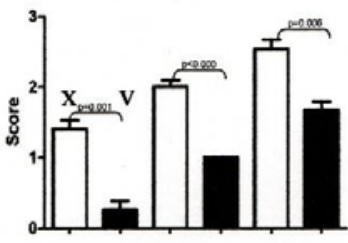

$1 \mathrm{md} 1 \mathrm{mw} 2 \mathrm{md} 2 \mathrm{mw} 3 \mathrm{md} 3 \mathrm{mw}$

c)

Fatty tissue

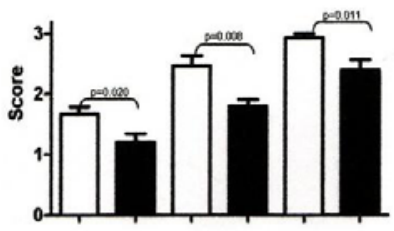

$1 \mathrm{md} 1 \mathrm{mw} 2 \mathrm{md} 22 \mathrm{mw} 3 \mathrm{md}, 3 \mathrm{mw}$ b)

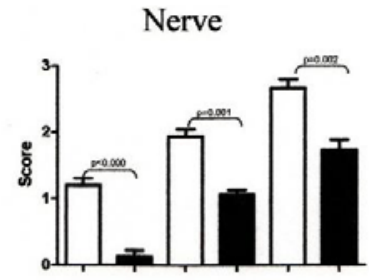

$1 \mathrm{md} 1 \mathrm{mw} 2 \mathrm{md} 2 \mathrm{mw} 3 \mathrm{md} 3 \mathrm{mw}$

d)

\section{Dermis}

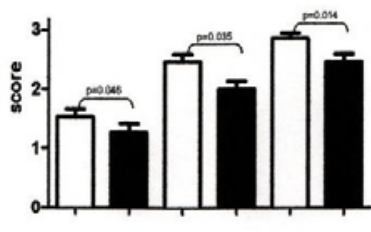

$1 \mathrm{md} 1 \mathrm{mw} 2 \mathrm{md} 2 \mathrm{mw} 3 \mathrm{md} 3 \mathrm{mw}$ e)

\section{Muscle}

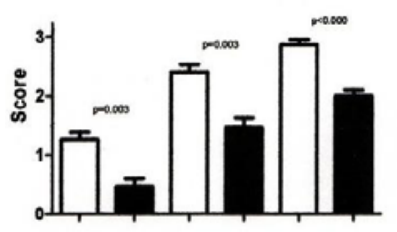

$1 \mathrm{md} 1 \mathrm{mw} 2 \mathrm{md} 2 \mathrm{mw} 3 \mathrm{md} 3 \mathrm{mw}$

Figure 6: Decomposition score of the pig legs: dry sea soil compared with wet sea soil.

a) blood vessels, b) nerves, c) fat tissue, d) dermis, e) muscle.

Open bars: dry sea soil (1, 2, $3 \mathrm{md}$ ); Closed bars: wet sea soil (1, 2, $3 \mathrm{mw})$

$x$ : $p<0.05: 2$ months compared with 1 month;

$v$ : $p<0.05$ : 3 months compared with 2 months.

\section{Conclusion}

In conclusion, although the authors are aware that many other influences will have different accelerating or decelerating effects on the rate of decomposition (such as clothing or the position of the body in the soil). Regarding the initial question in this case of whether the adult man could have been buried for three months, analysis of the burial pit and results from the pig leg decomposition model suggest that it is possible and, indeed, likely that the man was buried for three months in the moist sea sand.

The above also shows that the burial environment is not static during the process of decomposition it will change in time. Further studies and experiments will be carried out to understand the effects of belowground decomposition on human tissues in more detail.

\section{Acknowledgement}

This study was financed by the Dutch Ministry of Justice.

\section{References}

1. Efremov JA (1940) Taphonomy: New branch of paleontology. Pan-American Geology 74: 81-93.

2. Behrensmeyer AK (1978)) Taphonomic and ecologic information from bone weathering. Paleobiology 4:150-162.

3. Gordon CC, Buikstra JE (1989) Soil pH, bon preservation and sampling bias at mortuary sites. American Antiquity 46: 566-571.

4. Nawrocki SP (1995) Taphonomic processes in historic cemeteries, in: Grauer AL (Ed.), Bodies of evidence. Reconstructing history through skeletal analysis, Wiley-Liss, New York.

5. Lyman RL (1994) Vertebrate tapohonomy, Cambridge University Press Cambridge.

6. Nielsen-Marsh CM, Smith $\mathrm{Cl}$, Jans MEE, Nord A, Kars H, et al. (2007) Bone diagenesis in the European Holocene II: Taphonomic and environmental considerations. J Archaeol Sci 34: 1523-1531.

7. Waldron $T$ (1987) The relative survival of the human skeleton: implications for paleopathology, in: Boddington A, Garland AN, (Eds.), Death, decay and reconstruction. Approaches to archaeology and forensic science, Manchester University Press, Manchester, 55-64.

8. Garland AN (1987) A histological study of archaeological bone decomposition in: A. Boddington, A.N. Garland \& R.C. Janaway (Eds.), Death, decay and reconstruction. Approaches to archaeology and forensic science, Manchester University Press, Manchester, 109-126.

9. Guy H, Masset C, Baud CA (1997) Infant taphonomy. Int. J Osteoarchaeol 7 : 221-229.

10. Garland AN, Janaway RC () The taphonomy of inhumation burials, in: Roberts CA, Lee F, Bintliff J (eds.), Burial archaeology. Current research, methods and developments. British Archaeological Reports (BAR) 211: 1-293.

11. Haglund WD, Sorg MH (1997) Introduction to forensic taphonomy, in: Haglund WD, Sorg MH (Eds.), Forensic taphonomy. The post-mortem fate of human remains, CRC Press, Boca Raton, FL, pp. 1-9.

12. Sledzik PS (1998) Forensic taphonomy: post-mortem decomposition and decay, in: Reichs K (Ed.), Forensic osteology. Advances in the identification of human remains. Charles C Thomas Publisher, Springfield, USA, 109-119.

13. Sorg MH, Haglund WD (2002) Advancing forensic taphonomy: purpose theory and practice, in: Haglund WD, Sorg MH (Eds.), Advances in forensic taphonomy. Method, theory, and archaeological perspectives. CRC Press, Boca Raton, FL, USA, 3-29.

14. Haglund WD (2005) Forensic taphonomy, in: James SH, Nordby JJ (Eds.) Forensic science: An introduction to scientific and investigative techniques. CRC Press, Boca Raton, FL, USA, 119-133.

15. Tibbett $M$ (2008) The basics of forensic taphonomy: understanding cadaver decomposition in terrestrial gravesites, in: Oxenham $M$ (Ed.), Forensic approaches to death, disaster and abuse, Australian Academic Press, Sidney, Austrelia, 29-36. 
Citation: van de Goot FRW, Begieneman MPV, Groen MWJ, Gerretsen RRR, van Erp MAJJ, et al. (2012) Moisture Inhibits the Decomposition Process of Tissue Buried in Sea Sand: A Forensic Case Related Study. J Forensic Res 3:176. doi:10.4172/2157-7145.1000176

16. Carter DO, Yellowlees D, Tibbett M (2010) Moisture can be the dominant environmental parameter governing cadaver decomposition in soil. Forensic Sci Int 200: 60-66.

17. Hochrein MJ (1997) The dirty dozen: the recognition and collection of toolmarks in the forensic geotaphonomic record. Journal of Forensic Identification 47 171-198.

18. Hochrein MJ (2002) Autopsy of the grave: recognizing, collecting, and preserving forensic geotaphonomic evidence, in: Haglund WD, Sorg MH (Eds.), Advances in forensic taphonomy. Method, theory, and archaeological perspectives. CRC Press, Boca Raton, FL, USA, 45-70.

19. The Epos of Gilgamish, Tablet 1.

20. Werner U Spitz, Daniel J Spitz (1993) Time of death and changes after death Spitz and Fisher's medico legal investigations of death: Guidelines for the forensic applications of pathology to crime investigation (3rd edn), Springfield, Charles C Thomas, USA

21. Fierro MF (1993) Identification of Hunam Remains. Spitz and Fisher's medico legal investigations of death: Guidelines for the forensic applications of pathology to crime investigation (3rd edn), Springfield: Charles C Thomas.

22. Dimaio DJ, Dimaio VJM (1989) Forensic Pathology, New York, Elsevier.

23. Knigt B (2004) Forensic pathology, (3rd edn), Oxford University press.

24. Roulson J, Benbow EW, Hasleton P S, Discrepancies between clinical and autopsy diagnosis and the value of post mortem histology; a meta-analysis and review, Department of Histopathology, Christie Hospital, Department of Histopathology, Manchester Royal Infirmary, and Department of Histopathology, South Manchester University Hospitals Trust, Manchester, UK.

25. Junqueira LC (1981) Functionele histology, vierde editie, Uitgeverij Bunge Utrecht.

26. Turner B, Wiltshire P (1999) Experimental validation of forensic evidence: a study of the decomposition of buried pigs in a heavy clay soil. Forensic Sci Int 101: 113-122.

27. Archer MS (2004) Rainfall and temperature effects on the decomposition rate of exposed neonatal remains. Sci Justice 44: 35-41.

28. Forbes SL, Dent BB, Stuart BH (2005) The effect of soil type on adipocere formation. Forensic Sci Int 154: 35-43.

29. Forbes SL, Stuart BH, Dent BB (2005) The effect of the burial environment on adipocere formation. Forensic Sci Int 154: 24-34

30. Forbes SL, Stuart BH, Dent BB (2005) The effect of the method of burial on adipocere formation. Forensic Sci Int 154: 44-52.

31. Zimmerman KA, Wallace JR (2008) The potential to determine a postmortem submersion interval based on algal/diatom diversity on decomposing mammalian carcasses in brackish ponds in Delaware. J Forensic Sci 53: 935941

32. Dekeirsschieter J, Verheggen FJ, Gohy M, Hubrecht F, Bourguignon L, et al. (2009) Cadaveric volatile organic compounds released by decaying pig carcasses (Sus domesticus L.) in different biotopes. Forensic Sci Int 189: 4653.

33. Michaud JP, Moreau G (2009) Predicting the visitation of carcasses by carrionrelated insects under different rates of degree-day accumulation. Forensic Sci Int 185: 78-83.

34. MacAulay LE, Barr DG, Strongman DB (2009) Effects of decomposition on gunshot wound characteristics: under cold temperatures with no insect activity. J Forensic Sci 54: 448-451.

35. Stokes KL, Forbes SL, Tibbett M (2009) Freezing skeletal muscle tissue does not affect its decomposition in soil: Evidence from temporal changes in tissue mass, microbial activity and soil chemistry based on excised samples. Forensic Sci Int 183: 6-13.

36. Hopkins DW, Wiltshire PEJ, Turner BD (2000) Microbial characteristics of soils from graves: an investigation at the interface of soil microbiology and forensic science. Applied Soil Ecology 14: 283-288

37. Wilson AS, Janaway RC, Holland AD, Dodson HI, Baran E, et al. (2007)
Modelling the buried human body environment in upland climes using three contrasting field sites. Forensic Sci Int 169: 6-18.

38. Bardgett R (2005) The biology of soil. A community and ecosystem approach Oxford University Press, Oxford,

39. Swift MJ, Heal OW, Anderson JM (1979) Decomposition in terrestria ecosystems. Blackwells Scientific Publication, Oxford, USA

40. Boddington A, Garland AN (1987) Death, decay and reconstruction Approaches to archaeology and forensic science, Manchester University Press, Manchester, UK, 43-54.

41. Janaway RC (1996) The decay of buried human remains and their associated materials, in: Hunter J, Roberts C, Martin A (Eds.), Studies in crime: an introduction to forensic archaeology. Routledge, London, UK, 58-85.

42. Rodriguez WC (1997) Decomposition of buried and submerged bodies, in Haglund WD, Sorg MH (Eds.), Forensic taphonomy. The post-mortem fate of human remains, CRC Press, Boca Raton, FL, pp. 459-467.

43. Manhein MH (1997) Decomposition rates of deliberate burials: a case study of preservation, in: Haglund WD, Sorg MH (Eds.), Forensic taphonomy. The postmortem fate of human remains. CRC Press, Boca Raton, FL, USA, 469-481.

44. Dent BB, Forbes SL, Stuart DH (2004) Review of human decomposition process in soil. Environmental Geology 45: 576-585

45. Tibbett M, Carter DO, Haslam T, Major R, Haslam R (2004) A laboratory incubation method for determining the rate of microbiological degradation of skeletal muscle tissue in soil. J Forensic Sci 49: 560-565.

46. Carter DO, Tibbett M (2008) Cadaver decomposition and soil: processes, in: Tibbett M, Carter DO (Red.), Soil analysis in forensic taphonomy. Chemical and biological effects of buried human remains, CRC Press, Boca Raton, FL, USA, 29-51.

47. Mann RW, Bass WM, Meadows L (1990) Time since death and decomposition of the human body: variables and observations in case and experimental field studies. J Forensic Sci 35: 103-111.

48. Micozzi MS (1991) Post-mortem change in human and animal remains. A systematic approach, Charles C Thomas Publisher, Springfield IL, USA.

49. Carter DO, Yellowlees D, Tibbett M (2008) Temperature affects microbial decomposition of cadavers (Rattus rattus) in contrasting soils. Applied Soil Ecology 40: 129-137.

50. Hopkins DW (2008) The role of soil organisms in terrestrial decomposition, in Tibbett M, Carter DO (Red.), Soil analysis in forensic taphonomy. Chemical and biological effects of buried human remains, CRC Press, Boca Raton, FL, USA, 53-66

51. Evans WED (1963) The chemistry of death. Charles C Thomas, Springfield, IL.

52. Mant AK (1987) Knowledge acquired from post-war exhumations, in: Boddington A, Garland AN (Eds.), Death, decay and reconstruction. Approaches to archaeology and forensic science, Manchester University Press, Manchester UK, 65-78.

53. Shkrum MJ, Ramsay DA (2007) Forensic pathology of Trauma. Chapter 2- post mortem changes. Huma Press inc. NJ, USA

54. Carter DO, Tibbett M (2006) Microbial decomposition of skeletal muscle tissue (Ovis aries) in a sandy loam soil at different temperatures. Soil Biology and Biochemistry 38: 1139-1145.

55. Statheropoulos M, Agapiou A, Spiliopoulou C, Pallis GC, Sianos E (2007) Environmental aspects of VOCs evolved in the early stages of human decomposition. Sci Total Environ 385: 221-227.

56. http://www.ihcworld.com/_protocols/special_stains/HE_Harris.htm

57. http://www5d.biglobe.ne.jp/ hasumi/method/azan_e.html

58. Kootker LM (2009) Bodemkundig onderzoek op vier grondmonsters, Institute for Geo- and Bioarchaeology, Vrije Universiteit, Amsterdam.

59. Payne D, Gregory P (1988) The temperature of the soil, in: A. Wils (Ed.) Russel's soil conditions and plant growth, Longman Scientific and Technical, Harlow, pp. 282-297. 